\title{
THE EFFECT OF SOCIAL SECURITY ON DIVORCE AND REMARRIAGE BEHAVIOR
}

\author{
Stacy Dickert-Conlin* \\ Cristian Meghea \\ CRR WP 2004-09 \\ Released: April 2004 \\ Draft Submitted: March 2004 \\ Center for Retirement Research at Boston College \\ 550 Fulton Hall \\ 140 Commonwealth Ave. \\ Chestnut Hill, MA 02467 \\ Tel: 617-552-1762 Fax: 617-552-1750 \\ http://www.bc.edu/crr
}

* Stacy Dickert-Conlin is an assistant professor of economics at Syracuse University and a senior research associate at the Center for Policy Research. Cristian Meghea is a graduate assistant at the Center for Policy Research at Syracuse University. The research reported herein was performed pursuant to a grant from the U.S. Social Security Administration (SSA) to the Center for Retirement Research at Boston College (CRR). The opinions and conclusions are solely those of the authors and should not be construed as representing the opinions or policy of the SSA or any agency of the Federal Government or of the CRR. The authors would like to thank Hilary Hoynes and David Weaver for very constructive comments.

(C) 2004, by Stacy Dickert-Conlin and Cristian Meghea. All rights reserved. Short sections of text, not to exceed two paragraphs, may be quoted without explicit permission provided that full credit, including $\odot$ notice, is given to the source. 


\section{About the Center for Retirement Research}

The Center for Retirement Research at Boston College, part of a consortium that includes parallel centers at the University of Michigan and the National Bureau of Economic Research, was established in 1998 through a grant from the Social Security Administration. The goals of the Center are to promote research on retirement issues, to transmit new findings to the policy community and the public, to help train new scholars, and to broaden access to valuable data sources. Through these initiatives, the Center hopes to forge a strong link between the academic and policy communities around an issue of critical importance to the nation's future.

\section{Center for Retirement Research at Boston College}

550 Fulton Hall

140 Commonwealth Ave.

Chestnut Hill, MA 02467

phone: 617-552-1762 fax: 617-552-1750

e-mail: crr@bc.edu

http://www.bc.edu/crr

Affiliated Institutions:

American Enterprise Institute

The Brookings Institution

Massachusetts Institute of Technology

Syracuse University

Urban Institute 


\section{ABSTRACT}

This paper investigates the effects of economic incentives on divorce and remarriage behavior. Before December 1977, the Social Security law entitled divorcees to claim auxiliary benefits on their ex-spouse's record only if the marriage lasted at least 20 years. One of the 1977 amendments of the Social Security rules shortened the minimum duration of an "eligible" marriage to ten years. Following the passage of the law, we find that the divorce rate at nine years of marriage decreased relative to a control group. However, there is not strong evidence of a corresponding increase in the divorce rate at ten years of marriage. We also find no evidence that the new claim on future Social Security benefits affected divorced women's remarriage probability in the predicted way.

"We can never insure one-hundred percent of the population against one-hundred percent of the hazards and vicissitudes of life. But we have tried to frame a law which will give some measure of protection to the average citizen and to his family against the loss of a job and against poverty-ridden old age." Franklin D. Roosevelt's Presidential Address, August 14, 1935.

"Imagine a Retirement Program that...grants people who signed divorce papers after being married nine years and eleven months hundreds of thousands of dollars less than those who waited another month to divorce." Steuerle and Favreault, November 2002, Social Security For Yesterday's Family.

"Dear Ann Landers: You would do your readers a great service if you called to their attention the new Social Security law (effective Jan. 1, 1979) which ...reduces from 20 years to 10 years the time that a divorced person need have been married in order to claim benefits based on the ex-spouse's earnings." Landers, Ann. 1978. "Dear Ann Landers.” The Washington Post, April 7. Style Section: C16. 


\section{INTRODUCTION}

Many of the reforms instituted as part of the 1977 Amendments to the Social Security Act reflected a concern about whether program rules were keeping pace with modern demographic trends, a concern that still exists today. In particular, prior to the reforms, one could claim Social Security benefits on an ex-spouse's earnings record only if the marriage lasted at least 20 years. The 1977 amendments reduced the minimum duration of an eligible marriage to ten years. The law change intended to provide a safety net for the increasing numbers of divorced women entering retirement. A possible unintended consequence of the legislation, however, is that the retirement population would be composed of greater numbers of divorced women, a group with a disproportionately high poverty rate. This could happen if the law change increased divorce rates or lowered remarriage rates among divorced women

This study investigates whether the exogenous 1977 change in the Social Security rules on post-marriage benefits affected the divorce and the remarriage decisions of women. In particular, we ask whether the lower duration of an eligible marriage altered divorce behavior and whether a new claim on future Social Security benefits changed the remarriage behavior of divorced women?

While the law intends to target benefits toward those with the most need, it reflects the classic tradeoff in program design by introducing the potential to distort behavior. While a relatively large literature investigates the effect of government programs on marriage and divorce decisions, to our knowledge, this is the first paper to consider this particular rule in Social Security. Theoretically, Becker, Landes and Michael (1977) argue that individuals compare the costs and benefits of marriage relative to being single and choose to be unmarried if the utility from being single is greater than that of being married. To support this theory, there is growing evidence that the implicit penalties or subsidies 
provided by government programs influence propensities and timing of divorce and marriage. ${ }^{1}$ For example, while Alm and Whittington (1997), Sjoquist and Walker (1995), and Gelardi (1996) find that couples with high marriage penalties are more likely to delay marriage into the following tax year, Alm and Whittington (1997) find no evidence that taxes influence the timing of divorce. The literature on Social Security and marriage is more scarce, although at least two papers find that widow(er)s respond to Social Security (Brien, Dickert-Conlin and Weaver, forthcoming) and the Canadian Income Security system (Baker, Hanna and Kantarevic, forthcoming) by delaying or avoiding marriage to prevent losing a claim on widow benefits. The present study is one of only a few to address the effect of Social Security rules on family structure decisions.

With the evolution of divorce as a common family event in the U.S., understanding the interaction between Social Security and divorce decisions is particularly relevant. ${ }^{2}$ Butrica and Iams (1999) find, for the 1931 to 1935 birth cohort, that 11 percent of the women entering retirement are divorced, and they project an increase to 19 percent over the next 20 years. Divorced women are a particularly economically vulnerable group, facing a high risk of poverty in their later years - Anzick and Weaver (2001) show that 20.4 percent of divorced elderly women are poor as compared to 4.3 percent for married women.

Using data from the National Vital Statistics System, 1980 Census, and June supplements of the Current Population Survey (CPS), we exploit the 1977 law change to identify the effect of Social Security benefits on divorce behavior and remarriage. Following the passage of the law, we find that the divorce rate at nine years of marriage decreased relative to a control group as we might predict because of the benefit of having a ten year marriage. However, there is not strong evidence of a corresponding increase in the divorce rate at ten years of marriage. We also find no evidence that the

${ }^{1}$ See Alm, Dickert-Conlin and Whittington (1999) for a review regarding tax and transfer programs. Moffitt (1998) provides a survey focused on the welfare literature. 
new claim on future Social Security benefits provided by the 1977 law affected divorced women's remarriage probability in the predicted way.

Section 2 of the paper describes the divorce and remarriage rules of the Social Security program and their predicted effects on divorce and remarriage behavior. Section 3 presents empirical results on divorce behavior; and Section 4 estimates the effect of the Social Security rules on remarriage behavior. Section 5 concludes our study and outlines future research.

\section{Institutional Details of the Social Security Program: Divorce and Remarriage}

Retired workers receive Social Security benefits if they accumulated at least ten years of covered earnings over their work lives (U.S. Social Security Administration, 2001). Benefits are based upon a primary insurance amount (PIA) computed from their average indexed monthly earnings. One may also be eligible for Social Security "auxiliary benefits" as the spouse or ex-spouse of a covered worker. In practice, these benefits accrue almost entirely to women (see Table 5.A1 in U.S. Social Security Administration, 2001). To be eligible as an ex-spouse, the law requires that the marriage lasted at least ten years. A marriage lasting any amount less than ten years does not generate benefits for the divorced spouse. If the marriage qualifies under the ten year rule, the benefits are identical to those a spouse collects. Spousal benefits are equal to one-half of the husband's PIA upon reaching normal retirement age, or an actuarially reduced benefit if the claim is made before the normal retirement age. Spousal benefits are even more generous if the spouse or exspouse dies and they become survivor benefits. A woman can claim survivor benefits at an earlier age than the spousal benefits and survivor benefits are paid at a higher rate (potentially equal to 100 percent of the PIA).

${ }^{2}$ The ratio of divorces to marriages in a given year has increased from 0.23 in 1950 to 0.49 in 1996 (2001 Statistical Abstract of the U.S., Table 68). 
Spousal benefits are relevant even for women who themselves worked under covered employment. After computing auxiliary benefits based on each eligible marriage, SSA compares the woman's retired-worker benefits with the highest spousal or survivor benefit available. ${ }^{3}$ If these auxiliary benefits are higher than her retired-worker benefits, she is considered dually entitled, and SSA supplements her worker benefits to make them equal to the auxiliary benefits she is entitled to. If the retired-worker benefits are larger, the woman will not receive any auxiliary benefits.

Eligibility for divorced spouse benefits terminate if the woman remarries (and remains remarried), but surviving divorce spouse benefits are payable if the remarriage occurs at age 60 or later. ${ }^{4}$ A divorced woman's claim is unaffected by the remarriage of her ex-husband.

The current requirement that a marriage last at least ten years for a woman to be eligible was passed as part of the 1977 Amendments to the Social Security Act. The main provisions of the 1977 bill (in effect since January 1979) addressed the financing problems of the program (Myers, 1993). However, rising divorce rates in the 1960s and 1970s prompted the switch from a 20 to a ten-year minimum marriage. The change in the Social Security benefits was designed to help the increasing number of people divorcing after fewer years of marriage. The law applied to all existing divorced persons, not just those divorces that occurred after the law.

The 1977 law change provided women with ten to nineteen years of marriage with a claim on a future stream of income based on the ex-husband's work record if the marriage ends in divorce. We predict that the higher permanent income outside of marriage should increase the divorce rate within this group. ${ }^{5}$ In contrast, the 1977 law increased the gains to remaining married for the group of women married for fewer than ten years. Prolonging the marriage to reach the tenth anniversary now provides

\footnotetext{
${ }^{3}$ In practice, few divorced women age 62 or more had two or more marriages lasting at least ten years.

${ }^{4}$ Prior to 1984 , the remarriage of a surviving divorced spouse terminated her benefits.

${ }^{5}$ The effect of the program rules on divorce may work through either the propensity to divorce or the timing of the divorce. Clearly there are different welfare implications if a couple is deciding whether or not to divorce or
} 
potentially high rewards. We argue that is more costly to postpone a divorce that is further from the ten-year threshold. Living in an unhappy marriage and deferring the search for a new partner are examples of such costs that increase with a longer "waiting" period.

The change in the law also has implications for remarriage behavior. The law gives divorced women married at least ten years a claim on guaranteed future Social Security benefits and therefore increases their expected gains from being single. We predict that, everything else equal, the higher future wealth makes a divorced woman in this group less likely to remarry under the new law.

To give a sense of the number of women for whom the claim to an ex-spouse's benefit is relevant, Butrica and Iams (2000) estimate, using Social Security Administration data, 12 percent of women reaching the normal retirement age between 1996 and 2000 were divorced, and predict that this figure will increase to 20 percent in the next twenty years. In addition, 46 percent of divorced women born in the years 1931 through 1935 receive some sort of auxiliary benefits at age $67 .^{6}$

\section{DIVORCE BEHAVIOR}

\subsection{Data and Identification Strategy}

We use the 1977 law change as a natural experiment to identify an effect of changing financial incentives on divorce behavior. We define the period after the law change as any year after 1977.

Although the law was not effective until 1979, the law passed in 1977 and marriages that ended in 1978 would be eligible for the full benefits described in the law, beginning in 1979. In addition, the law was publicized in 1978 in places like Ann Lander's (1978) newspaper column and a front-page article of the Washington Post (Rich, 1978), so we assume that 1978 represents the "after" period.

simply when to divorce. This study does not attempt to disentangle the two effects but, at least with respect to behavioral responses to taxation, Slemrod (1990) suggests that timing is the highest order effect.

${ }^{6}$ They estimate 13 percent receiving only auxiliary benefits and the remaining 33 percent as dually entitled. 
As a first step in considering the question of whether the law affects divorce decisions, we look at the number of divorces by duration of marriage from the Vital Statistics (VS) data for the United States. The VS, compiled by the National Center for Health Statistics, contains information from divorce certificates collected at the state level in the United States for every year from 1968 to $1995 .^{7}$ It is a random sample of records in some states and the entire universe of records in other states. ${ }^{8}$ Only about half of all states participated in the divorce reporting. A typical record contains the date of divorce (month and year), the date of marriage (month and year), state of divorce, and information on both spouses, including their marital and fertility history. Figure 1 shows the average divorce counts by marriage duration in multi-year, calendar time intervals. Figures 2 and 3 highlight marriage durations of particular interest from Figure 1. We include 1978, the year after the law was passed, separately, in case there is a one time effect of the law change. For the purpose of consistency we keep only divorces from first marriages in the 25 states that reported continuously from 1968 until 1995. This figure shows that the counts of divorces rose dramatically after the 1969 to 1972 period. The count numbers peaked in the 1979 to 1982 span and then fell slightly after that. Over time, the distribution shifted toward shorter marriage durations.

With respect to our hypotheses, Figures 1, 2 and 3 illustrate a number of things. There are no dramatic declines in the number of divorces at a marriage duration of nine years, with a corresponding increase at 10 years after the 1977 law change. In 1978, there is some evidence of a relatively low number of divorces after nine year marriages, but there is no obvious increase in the number of divorces after 10 years in subsequent years. Prior to the law change in 1978, we might expect fewer divorces after 19 years of marriage and more divorces after 20 years of marriage, if women waited to secure a claim to spousal benefits before divorces. However, no such pattern exists in the data. As

${ }^{7}$ Funding ended for this project after 1995. 
the Figures 1 and 3 illustrate, there are so few divorces that occur around 20 years of marriage duration, that we focus the remainder of our analysis on the implication of the law around ten year marriages.

The data in the figures may not fully capture the environment, because they fail to account for the number of marriage at risk of divorce and other secular and demographic trends. Our more formal empirical analysis relies on identification through a treatment and control setting. We assume that some set of marriages are unaffected by the law change (control group) and another set of marriages are affected by the law change (treatment group). To cleanly isolate an effect of the law, we look for treatment and control groups that are equivalent, conditional on observables, except for the law change. Ultimately, we choose seven-year marriages as our control group and nine and ten year marriages as our treatment groups. Seven-year marriages are likely to serve as a good control group because the costs of delaying divorce three years to guarantee a claim on future Social Security benefits are likely to be prohibitively high, so the seven-year marriages are unlikely to be affected by the 1977 law change. We choose marriages of nine years and marriages of ten years as our treatment groups because, conditional on unobservables, these marriages should be similar to seven-year marriages and we have clear predictions about how these marriages should be affected by the law. Relative to marriages of seven year duration, we expect a decrease in marriages ending after nine years and an increase in marriages ending after 10 years.

Statistically reliable estimates based on single year marriage durations in single calendar years require very large data on divorces, such as those found in the VS. ${ }^{9}$ Unfortunately, these data are not

${ }^{8}$ Each record represents one divorce and is weighted based on the sampling rate of the reporting area. The information regarding the divorce and the spouses is obtained from the certificate of the granted divorce. Marital history includes the number of marriages for both spouses. In all our analyses, we use appropriate weights.

${ }^{9}$ We experimented with the June CPS, which has retrospective marital histories, but the data were very noisy at the single calendar year, single marital duration level. 
rich in other observables. Only age and state are consistently reported, while education, number of marriages, and number of children are not.

We estimate the population at risk of divorce and create divorce rates using the 5 percent 1980 Census public-use microdata sample. ${ }^{10}$ These Census data contain records for a sample of households, with information on the characteristics of each unit and the people in it. We restrict the analysis of divorce rates to divorces following a first marriage because these are the only marriages in the 1980 Census for which we can reliably estimate duration. ${ }^{11}$ From this, we estimate the number of existing first marriages in 1980, by marriage duration and by wife's age. (YES to the comment) Then, by subtracting out the divorce counts taken from VS, we estimate the yearly counts of married couples in the years following 1980 by duration of marriage and wife's age. ${ }^{12}$ Similarly, we add in divorce counts to estimate the counts of married couples in the years before $1980 .{ }^{13}$ We restrict our Census data to the states included in the divorce reporting area and match the Census denominator with the VS numerator by marriage duration and the wife's age to estimate the yearly divorce rates.

Our method of estimating the divorce rates has certain disadvantages. First, because the Census is not retrospective we could not create rates by number of children, which is potentially relevant when making a divorce decision. Second, we lack information on Social Security eligibility from Census or VS data. Therefore, our identification of an effect of the law relies on the difference of the divorce rates between the control and the treatment groups.

The remainder of our divorce rate analysis considers only the years 1973 to 1982 in order to minimize the effect of large secular changes in divorce attitudes. This choice increases the number of

\footnotetext{
${ }^{10}$ The 1990 Census did not contain marital history information and the 1970 Census is further from our period of interest than the 1980 Census, so we limit our analysis to estimates from the 1980 Census.

${ }^{11}$ The 1980 Census only asked married respondents to report the month and year their first marriage began.

${ }^{12}$ We cannot identify widowhood in our Census sample, but we do not expect any correlation with the law

change, hence no induced bias in the results.

${ }^{13}$ For example, to estimate the number of women age 36 and married for 11 years in 1981, we start with the counts of women age 35 and married for 10 years in 1980 and subtract the divorces of women age 35 and married for 10 years in 1980 .
} 
states in our sample to 28 , and minimizes some of the issues of projecting estimates of the number of marriages from a single cross section of marriages (1980).

Figure 4 presents the trend of divorce rates for our durations of interest during the period 1973 to 1982 . We see an increase in the divorce rate of the control group, the seven-year long marriages. We also see an increase in the divorce rate of the women married for both nine and ten years following the law change. However, the smaller increase in the divorce rate of the women married nine years may suggest that some women delay their divorce decision until the marriage becomes eligible for auxiliary benefits. We investigate this in the next subsection.

\subsection{Results}

For our more formal empirical analysis, we create divorce rates by five age categories: 19 to $32 ; 33$ to $42 ; 43$ to $52 ; 53$ to 62 and over 62 . Five age groups over ten years of data yields 50 observations in each of the treatment groups and the control group. Table 1 presents the divorce rates for the treatment and control groups in the years before and after the law change. The first column shows the divorce rate before the 1977 law change and the second column shows the divorce rate after the 1977 law change. The third column shows the differences within groups over time and the last column shows the differences in differences between the groups.

One concern with the 1973 to 1982 time frame is that the treatment and control groups do not differ simply by the law change but by other unobservable changes over time. It is not clear in which way this might bias our results. To address this issue, we also perform our analysis on the year immediately before the law was passed 1977 and the year after the law was passed, 1978, under the assumption that the only difference between the control and treatment groups is the law change. This restriction leaves us with only ten observations in each of the treatment groups and the control group. 
Panel A considers all years between 1973 and 1982 and Panel B considers only 1977 and 1978. We find that the divorce rate for the control group of 7-year marriages increased over this period by 0.36 percentage points (from 1.16 percent to 1.52 percent). The divorce rate for the 9-year marriage treatment group also increased over this period by 0.33 percentage points (from 0.95 percent to 1.28). Our first estimate of the effect of the 1977 law change is that it lowered the divorce rate at nine years by $0.03(0.33-0.36)$ percentage points. Women for whom the benefits of delaying divorce increased were less likely to divorce. However, with a standard error of 0.31 , this difference in difference is not statistically significant. This effect is true in Panel B as well, where we show that the probability of divorce decreased by 0.22 percentage points in the control group relative to the treatment group. Again, this difference in difference is not statistically significant at standard levels.

The results are not as predicted when we use ten year marriages as our treatment group. We expect that ten-year marriages might have higher dissolution rates after the law change, relative to the control group. In panel A we show that the divorce rate after ten years of marriages is higher by 0.21 percentage point in the years 1978 to 1982 , relative to the years 1973 to 1977 . This is a smaller increase than the 0.36 percentage point increase experienced by the control group. Our preliminary estimate of the effect of the 1977 law change on divorce rates at ten years of marriage is that it lowered, rather than raised, as predicted, the divorce rate by 0.15 percentage points. In these basic comparisons, we find no evidence that the law change increased divorce among ten-year marriages relative to our control group.

To strictly identify the effect of the law change, our estimation strategy assumes that the treatment and control groups are observationally equivalent except for the effect of the 1977 law change. Because of the lack of demographic detail in the VS data, we chose our treatment and control groups in a way that intends to control for differences. However, we now turn to regression analysis 
to see if other measurable factors such as age or year effects account for the differences we found in Table 1.

To account for observable differences in the treatment and control groups, we estimate the following Weighted Least Squares model:

$$
\text { divorce rate }_{t}=\beta_{0}+\beta_{1}^{*} \text { treatment }+\beta_{2}^{*} \text { after }+\beta_{3}^{*} \text { treatment } * \text { after }+X^{\prime} \beta_{4}+e_{t}
$$

where divorce rate is the yearly rate of divorce, treatment is a dummy that takes the value 1 if the rate refers to the treatment group, $\mathrm{t}$ indicates the year of the observation and $e_{t}$ is the error term. The variable after is a dummy indicating the period after the law change. The coefficient of interest is $\beta_{3}$. The interaction variable picks up any differential trends in divorce behavior between the treatment group and the control group comparing the period before with the years after the law change. We expect $\beta_{3}$ to be negative for the treatment group of women with nine years of marriage because the 1977 law should have made divorce less attractive for this group. Conversely, we expect this coefficient to be positive for women with ten years of marriage because the 1977 law would make divorce more attractive. The $\mathrm{X}$ vector contains single year effects, and dummies for the five different age categories. We weight cell observations by the inverse of variance of the divorce rate.

Table 2 presents the results of the regression analysis. Again we consider two time periods: one spanning 1973 to 1982 and one spanning just 1977 and 1978. First consider the results when the group with nine years of marriage is the treatment group. The coefficient on the interaction term between nine years of marriage and after the 1977 law change gives a measure of the average difference in the probability of divorce among nine-year relative to seven-year marriages after the 1977 law change. Confirming the results in Table 1, divorce rates are higher after the law change at seven and nine years of marriage, but the increase was smaller for nine-year marriages relative to seven-year marriages. The coefficient on the interaction term $(-0.08)$ is statistically significant at the 5 percent 
level $($ standard error $=0.03$ ) and suggests that the divorce rate at nine years of marriage increased by 0.08 percentage points less than the divorce rate for seven-year marriages, following the 1977 law change. Given that 0.95 percent of women with nine years of marriage were divorcing before the law change, the coefficient implies that the 1977 law change is correlated with an 8.4 percent decrease in the probability of divorcing in the ninth year of marriage.

In Column (3), we show the results when we restrict our sample to just 1977 and 1978. The coefficient of interest is smaller in magnitude (-0.02) and not statistically signific ant (standard error = 0.07). The decline in significance reflects the tradeoff between more accurate identification of the treatment effect and less precise estimates.

Columns (2) and (4) of Table 2 show the results of estimations in which women with ten years of marriage are the treatment group. The control group is still women with seven years of marriage. For the sample with the years 1973 to 1982 , the estimated coefficient on the interaction between the treatment group and after the law change is -0.09 and statistically significant at the ten percent level. The negative coefficient implies that the probability of divorce after the law change increases by an amount less than that of the control group of seven-year marriages, even after controlling for year and age effects. Given that 0.99 percent of women with ten years of marriage were divorcing before the law change, the coefficient implies that the 1977 law change was correlated with a 9 percent decrease in the probability of divorcing at ten years of marriage. When we restrict the sample to 1977 and 1978 only, the coefficient on the interaction term has the expected sign (0.03) but is not statistically significant at standard levels.

\subsection{Discussion}

Overall, our results show that the divorce rate at nine years of marriage decreased following the law that increased the rewards for maintaining a marriage for at least ten years. Also, there was a 
corresponding increase in the divorce rate at the ten-year marriage in the first year after the law went into effect, but the estimation results were not statistically significant. At best, this is weak evidence in support of a behavioral response to the law. One possible explanation for finding little response to the law is that the financial incentives in Social Security are too small to matter much in the divorce decision. Much of the previous literature on the effect of taxes and transfers finds small effects of these financial incentives on marriage behavior. In the case of Social Security, the financial benefits of waiting may be decades from the time the decision to divorce is being made. The fact that divorced women start receiving the auxiliary benefits only at retirement places these "divorce subsidies" too far into their future.

To get a sense of how large the spousal benefits could be, consider a woman born in the cohort 1941-1945, approaching her 10th anniversary of her marriage in 1977. If she retires at the normal retirement age and receives the predicted benefits for a divorced women of her age, her monthly benefits in 1998 dollars will be between $\$ 659$ and $\$ 1000$, depending on whether her ex-spouse is alive or not (Butrica and Iams, 2000, Table 3). If these women live 17 additional years beyond the time when they begin collecting Social Security, ${ }^{14}$ the present discounted value of their stream of spousal benefits at the time of her divorce is between $\$ 21,370$ and $\$ 28.475$ in 2004 dollars. While this estimate represents only a back of the envelope calculation, these numbers would seem to be a non-trivial amount.

Another reason for finding weak, if any, response to the law change is that people may not know about the law. Casting some skepticism on this proposed reason is that the law change received at least some media attention at the time. An April 1978 letter to Ann Landers (Landers, 1978) and a front page Washington Post article (Rich, 1978) in January of the same year detailed the law change. Most current books that advise women on the financial implications of a divorce give a cle ar 
description of the ten-year-marriage rule governing Social Security benefits. ${ }^{15}$ However, in the event that women rely on professional advice, a lawyer might focus the divorce financial recommendations on matters like alimony and child support, ignoring the Social Security benefits.

Finally, the value of the future Social Security benefits may be quite low if women expect to remarry and therefore acquire a claim to new auxiliary benefits or if women expect to rely on their own worker benefits, not auxiliary benefits. The majority of divorced women remarry eventually and almost two thirds of the remarriages occur within three years from divorce. ${ }^{16}$ In addition, Butrica and Iams (2000, Table 3) estimate around 50 percent of the divorced women retiring between 1996 and 2000 receive retired-worker benefits. They project the percentage to increase to 66 in the following twenty-five years.

\section{REMARRIAGE BEHAVIOR}

\subsection{Identification strategy}

We adopt a difference in difference strategy to test whether a claim to a future stream of Social Security benefits affects remarriage behavior. In this case, the divorced women previously married for ten years received a claim to a future stream of income when the Social Security law changed in 1977 . We use this group as our treatment group. However, women married only nine years did not receive this claim to a future stream of income and so they serve as our control group. Because results from the previous section suggest that the 1977 amendment may have affected the decision of when to divorce, and therefore determine who is in the treatment and control groups after

${ }^{14}$ Life expectancy for a typical 65 year old of this generation is 19 years (Butrica and Iams), although divorced women typically have lower life expectancies.

15 "The American Bar Association Guide to Family Law" (The American Bar Association, 1996), "Divorce for Dummies" (Ventura, Reed and Reed, 1998), and "Divorce Made E-Z" (Made E-Z, 2001), all have a clear and easy to find description of the eligibility requirements for Social Security auxiliary benefits. The latter one specifically cautions women who approach their $10^{\text {th }}$ anniversary of the marriage to make sure the divorce becomes final after the ten-year mark or lose substantial benefits. 
the law change, we restrict our analysis to women whose divorce occurred in 1976 and earlier. Our prediction is that the divorced women previously married ten years remarry less under the new SSA rules.

Again, we restrict our initial analysis to just nine-year versus ten-year old marriages because we believe that conditional on observable differences like work history and income, these two groups are similar. In a sensitivity test, we expand our control group to marriages of eight or nine years duration and the treatment group to ten or 11 years duration.

\subsection{Data}

For this analysis we pool the 1980, 1985, 1990, and 1995 June CPSs. A CPS record has demographic information on the respondent and the spouse, and, more importantly for our purpose, the marital and fertility history of the respondent. The CPS questionnaire asks details on the respondent's first, second and last marriage; the individual reports the date of marriage, dates of separation and of divorce, as well as the reason of ending each marriage. ${ }^{17}$

For reasons of consistency across the four waves of the survey, we keep only the women between 15 and 65 years of age. Because the law is slightly more complicated for women married more than once, we restrict our sample to divorce spells following a first marriage. We expand each divorce spell observation and create the variable remarried that takes the value 0 for each year of the divorce spell and 1 for the year when the spell ends in a remarriage, if any.

Table 3 shows that the treatment and control groups have similar characteristics, but the small economic differences are statistically different. For example, marriages that ended after nine years, relative to those that ended after ten years, are more likely to be women who are white, slightly

${ }^{16}$ Authors' calculations from June CPS. 
younger, have younger children and have lower education. These differences are all statistically different, but, surprisingly, the duration of the divorce spells are not statistically different from one another.

Figure 5 presents the remarriage rates (hazards) for the period 1973 to 1982 (we do not restrict our regression analysis to these years, but we show these years just to be comparable with our divorce analysis). Examining Figure 5, the law does not seem to have the predicted effect on remarriage. If anything, the remarriage probability of a woman with a ten or eleven year marriage is higher following the law change, relative to the remarriage rate of nine year marriages.

\subsection{Results}

Our more formal analysis begins a difference in difference analysis similar to Table 1 . We see from Table 4 that the probability of remarriage falls after 1977. In the control group of first marriages that lasted nine years, the probability falls by 7.4 percentage points. And, in the treatment group of first marriages that lasted ten years, the probability of remarriage falls by 6.5 percentage points. In contrast to our predictions, the probability of remarriage after the law change fell by more for the control group. However, the difference in difference is only 0.9 percentage points and is not statistically significant at standard levels. We find similar results when we expand our treatment and control groups to include 11 and eight year marriages.

\footnotetext{
${ }^{17}$ One of the concerns with the Current Population Surveys is the data quality because of their retrospective nature. Goldstein (1999) argues that both marriages and divorces are underreported and there are many missing responses imputed, yet using CPS for both numerator and denominator alleviates the severity of the problem.
} 
Because the presence of unmeasured demographic variables might be masking any effect of the law, we also estimate the probability of remarriage with a linear probability regression model. ${ }^{18}$ The equation takes the form

$$
\begin{aligned}
\text { remarried }_{i t}= & \alpha+\beta_{1}(10 \text { year })_{i t}+\beta_{2}\left(\text { after }_{i t}+\beta_{3}\left(10 \text { year }^{*} \text { after }_{i t}+\right.\right. \\
& X_{i t}{ }^{\prime} \beta_{4}+\beta_{5}(\text { duration })_{i t}+\beta_{6}\left(\text { duration }^{2}\right)_{i t}+\varepsilon
\end{aligned}
$$

where remarried takes the value 0 for each year of the divorce spell that the woman remains unmarried and 1 for the year when the spell ends in a remarriage, if any; 10year indicates that the observations is in the treatment group; after is a dummy that takes the value 1 if the year of the observation is 1978 or later; duration measures the length of the divorce spell in years; $i$ indexes the divorce spells, while $t$ denotes the year; and $\varepsilon$ is the error term. The other covariates in the vector $X$ include the respondent's age in years, a dummy for whether or not the woman is white, the number of children 6 and younger, and the number of children 18 and younger. The coefficient of interest is on the interaction term between 10year * after, $\beta_{3}$, which we predict will be negative if the claim to a future stream of income reduces the remarriage probability for women.

The first column of Table 5 reports the results from the regression comparing 9-year marriages with ten-year marriages. The coefficient of interest is a positive 0.012 , which does not have the expected sign, but is not statistically significant. Next, we expand our sample: the treatment group now contains divorced women previously married for ten or 11 years while divorced women previously married eight or nine years comprise the control group. The treatment and control groups are less likely to be identical on unobservable characteristics, but we gain from an increased sample size. In contrast to our predictions, the key coefficient is now 0.013 and becomes statistically significant at the five percent level.

${ }^{18}$ We find similar results with a maximum-likelihood complementary log-log model. Complementary log-log analysis is an alternative to probit and logit analysis but is unlike these other estimators in that the transformation 
Most of the estimates of the covariates have the expected sign in all specifications. Older women are less likely to remarry, and the presence of minor children decreases the chances of remarriage. Women with some college education, relative to women with a high school education also remarry less, possibly because the education gives them more financial independence.

\subsection{Discussion}

Our remarriage analysis suggests that a claim to future Social Security benefits did not decrease the probability that women remarry. As in the divorce case, we expect that the reasons why people do not respond to these incentives in the expected way may be that women are not familiar with the law, the present discounted value of the benefit is low at the time of remarriage decisions, or women are more likely to rely on their own work history than that of their ex-spouse.

\section{Conclus ion}

Overall, the Social Security "divorce subsidy" provided by the 1977 law change seems not to distort the marriage behavior in a systematic way. The program rules do not seem to have large behavioral effects on divorce or remarriage. With respect to divorce behavior, this finding is consistent with other work on taxes and the timing of divorce (Alm and Whittington, 1997). It may simply be that the timing of exiting a marriage is not sensitive to financial incentives. Whatever the reason, this finding has important implications for Social Security policy: legislative options to change the duration of marriage requirement are unlikely to encourage divorce or discourage remarriage.

Our results and the quote at the beginning of the paper suggest that the criticism of the current Social Security system on an equity basis may be the appropriate margin of criticism. There are clearly equity issues that are difficult to reconcile with the fact that an additional month of marriage for

is not symmetric. This model is typically used when the non-zero outcome is rare. 
someone married nine years and eleven months is the difference between a claim on Social Security and none.

In spite of not finding an effect of these financial incentives on marriage behavior, the incentives might trigger other responses like changes in the labor supply of the eligible divorced women.

This is a topic for future research. 


\section{References}

Alm, James, Stacy Dickert-Conlin and Leslie A. Whittington. 1999. "The Marriage Penalty." Journal of Economic Perspectives. 13(3). 193-204.

Alm, James and Leslie A. Whittington. 1997. "Income Taxes and The Timing of Marital Decisions.” Journal of Public Economics. 64(2): 219-40.

The American Bar Association. 1996. "The American Bar Association Guide to Family Law: The Complete and Easy Guide to All the Laws of Marriage, Parenthood, Separation and Divorce." Random House, Incorporated.

Anzick, Michael A. and David A. Weaver. 2001. "Reducing Poverty Among Elderly Women." ORES Working Paper Series. Social Security Administration, Washington, D.C.

Auerbach, Alan J. 1992. "On the Design and Reform of CapitatGains Taxation." American Economic Review. 82(2). 263-67.

Auerbach, Alan J. and Joel Slemrod. 1997. "The Economic Effect of the Tax Reform Act of 1986." Journal of Economic Literature. 35(2). 589-632.

Baker, Michael, Emily Hanna and Jasmin Kantarevic. forthcoming. "The Married Widow: Marriage Penalties Matter!" Journal of the European Economic Association.

Becker, Gary S. 1973. "A Theory of Marriage: Part I." The Journal of Political Economy. 81(4). 813-846.

Becker, Gary S. 1974. “A Theory of Marriage: Part II.” The Journal of Political Economy. 82(2). S11-S26.

Becker, Gary S., Elisabeth M. Landes and Robert T. Michael. 1977. ""An Economic Analysis of Marital Instability," Journal of Political Economy, 85(6): 1141-87.

Brien, Michael J., Stacy Dickert-Conlin and David A. Weaver. 2000. "Widows Waiting to Wed? (Re)Marriage and Economic Incentives in Social Security Widow Benefits.”'Working Paper, Syracuse University, Syracuse, NY.

Butrica, Barbara A. and Howard M. Iams. 2000. "Divorced Women at Retirement: Projections of Economic Well-Being in the Near Future." Social Security Bulletin. 63(3). 3-12.

Congressional Research Service. 2001. Welfare Reform: TANF Provisions Related to Marriage and Two-Parent Families. Washington, D.C.: Congressional Research Service.

Costa, Dora L. 1997. "Displacing the Family: Union Army Pensions and Elderly Living Arrangements." Journal of Political Economy. 105(6): 1269-92.

Costa, Dora L. 1999. "A House of Her Own: Old Age Assistance and the Living Arrangements of Older Nonmarried Women.” Journal of Public Economics. 72(1). 39-59. 
Dickert-Conlin, Stacy. 1999. "Taxes and Transfers: Their Effects on the Decision to End a Marriage." Journal of Public Economics. 73(2). 217-40.

Engelhardt, Gary V., Jonathan Gruber and Cynthia D. Perry. 2002. "Social Security and Elderly Living Arrangements.” NBER Working Paper No. 8911.

Friedberg, Leora. 1998. "Did Unilateral Divorce Raise Divorce Rates? Evidence from Panel Data." NBER Working Paper No. 6398

Gelardi, Alexander M.G. 1996. "The Influence of Tax Law Changes on the Timing of Marriages: A Two-Country Analysis." National Tax Journal. 49(1). 17-30.

Goldstein, Joshua R. 1999. "The Leveling of Divorce in the United States.” Demography. 36(3). 409-414

Hoynes, Hilary. 1997. “Does Welfare Play Any Role in Female Headship Decisions?” Journal of Public Economics. 65(2). 89-117.

Landers, Ann. 1978. “Dear Ann Landers.” The Washington Post, April 7. Style Section: C16.

Made E-Z. 2001. "Divorce Made E-Z.” Made E-Z Products.

McGarry, Kathleen and Robert F. Schoeni. 2000. "Social Security, Economic Growth, and the Rise in Elderly Widows' Independence in the Twentieth Century." Demography. 37(2). 221-36.

Milligan, Kevin. 2002. “Subsidizing the Stork: New Evidence on Tax Incentives and Fertility.” NBER Working Paper No. 8845.

Moffitt, Robert. 1994. "Welfare Effects on Female Headship with Area Effects." Journal of Human Resources. 29(2). 621-36.

Moffitt, Robert A. 1998. "The Effect of Welfare on Marriage and Fertility.” Robert A. Moffitt, ed. Welfare, The Family, and Reproductive Behavior: Research Perspectives. Washington, D.C.: National Academy Press, 1998.

Myers, Robert J. 1993. Social Security. Philadelphia: University of Pennsylvania Press.

Norton, Arthur J. and Louisa F. Miller. 1992. "Marriage, Divorce, and Remarriage in the 1990s." Current Population Reports: Special Studies. Series P-23, No. 180. Washington, D.C.: U.S. Census Bureau.

Phillips, Patricia and George Mair. 1995. "Divorce: A Woman's Guide to Getting a Fair Share." Peterson's.

Powers, Elizabeth T. and David Neumark. 2001. The Supplemental Security Income Program and Incentives to Take Up Social Security Early Retirement: Empirical Evidence from Matched SIPP and Social Security Administration Files.” NBER Working Paper No. 8670. 
Rich, Spencer. 1978. "Hill Widens Old-Age Aid For Women; Social Security Changes Reflect Women's Wider Role" Washington Post January 10, First Section; A1.

Sjoquist, David L. and Mary Beth Walker. 1995. "The Marriage Tax and the Rate and Timing of Marriage." National Tax Journal. 48(4). 547-58.

Slemrod, Joel. 1990. "The Economic Impact of the Tax Reform Act of 1986." Joel Slemrod, ed. Do Taxes Matter? The Impact of the Tax Reform Act of 1986. Cambridge, Mass.: MIT Press, $1-12$.

U.S. Census Bureau. 2000. Statistical Abstract.

http://www.census.gov/prod/2001pubs/statab/sec20.pdf

U.S. Census Bureau. 2001. Statistical Abstract. http://www.census.gov/prod/2002pubs/01statab/stat-ab01.html

U.S. Congress, Committee on Ways and Means. 2000. 2000 Green Book. Washington, D.C.: U.S. Government Printing Office.

U.S. Social Security Administration. 2001. Annual Statistical Supplement to the Social Security Bulletin, 1999. Washington, D.C.: U.S. Government Printing Office.

Ventura, John and Mary Reed Wiley. 1998. Divorce for Dummies. John \& Sons, Inc.

Whittington, Leslie A. and James Alm. 1997. "Till Death or Taxes Do Us Part: The Effect of Income Taxation on Divorce." Journal of Human Resources. 32(2). 388-412. 
Table 1

Divorce rates per 100 women

(Standard Errors in parenthesis)

\begin{tabular}{|c|c|c|c|c|}
\hline & $\begin{array}{c}\text { Pre-1977 } \\
\text { amendment } \\
\text { (1) }\end{array}$ & $\begin{array}{l}\text { Post-1977 } \\
\text { amendment } \\
\text { (2) }\end{array}$ & $\begin{array}{l}\text { Difference } \\
\text { (2)-(1) }\end{array}$ & $\begin{array}{c}\text { Difference-in- } \\
\text { differences } \\
\text { (Treatment- } \\
\text { Control) }\end{array}$ \\
\hline \multicolumn{5}{|c|}{ Panel A } \\
\hline \multicolumn{5}{|c|}{ Pre-1977 amendment years are 1973 to 1977 . Post } \\
\hline \multicolumn{5}{|l|}{$\mathrm{N}=50$ in each group } \\
\hline $\begin{array}{l}\text { A. Control group } \\
\text { 7-year old marriages }\end{array}$ & $\begin{array}{c}1.16 \\
(0.14)\end{array}$ & $\begin{array}{c}1.52 \\
(0.17)\end{array}$ & $\begin{array}{c}0.36 \\
(0.23)\end{array}$ & \\
\hline $\begin{array}{l}\text { B. Treatment group } \\
\text { 9-year old marriages }\end{array}$ & $\begin{array}{c}0.95 \\
(0.14)\end{array}$ & $\begin{array}{c}1.28 \\
(0.16)\end{array}$ & $\begin{array}{c}0.33 \\
(0.95)\end{array}$ & $\begin{array}{l}-0.03 \\
(0.31)\end{array}$ \\
\hline $\begin{array}{l}\text { C. Treatment group } \\
\text { 10-year old marriages }\end{array}$ & $\begin{array}{c}0.99 \\
(0.12)\end{array}$ & $\begin{array}{c}1.21 \\
(0.16)\end{array}$ & $\begin{array}{c}0.21 \\
(0.20)\end{array}$ & $\begin{array}{l}-0.15 \\
(0.30)\end{array}$ \\
\hline \multicolumn{5}{|c|}{ Panel B } \\
\hline \multicolumn{5}{|c|}{ Pre-1977 amendment year is 1977 . Post-1977 amendment year is 1978.} \\
\hline \multicolumn{5}{|l|}{$\mathrm{N}=10$ in each group } \\
\hline $\begin{array}{l}\text { D. Control group } \\
\text { 7-year old marriages }\end{array}$ & $\begin{array}{c}1.17 \\
(0.41)\end{array}$ & $\begin{array}{c}1.51 \\
(0.41)\end{array}$ & $\begin{array}{c}0.34 \\
(0.58)\end{array}$ & \\
\hline $\begin{array}{l}\text { E. Treatment group } \\
\text { 9-year old marriages }\end{array}$ & $\begin{array}{c}0.99 \\
(0.34)\end{array}$ & $\begin{array}{c}1.11 \\
(0.37)\end{array}$ & $\begin{array}{c}0.12 \\
(0.51)\end{array}$ & $\begin{array}{l}-0.22 \\
(0.77)\end{array}$ \\
\hline $\begin{array}{l}\text { F. Treatment group } \\
10 \text {-year old marriages }\end{array}$ & $\begin{array}{c}1.00 \\
(0.31)\end{array}$ & $\begin{array}{c}1.13 \\
(0.37)\end{array}$ & $\begin{array}{c}0.13 \\
(0.49)\end{array}$ & $\begin{array}{l}-0.21 \\
(0.75)\end{array}$ \\
\hline
\end{tabular}

Source: Vital Statistics and 1980 Census. Standard errors in parentheses. 
Table 2

Dependent Variable is the Divorce rate

Control Group is 7 year marriages

\begin{tabular}{|c|c|c|c|c|}
\hline & \multicolumn{2}{|c|}{$\begin{array}{c}\text { 1973-1982 } \\
\text { Treatment Group: }\end{array}$} & \multicolumn{2}{|c|}{$\begin{array}{c}\text { 1977-1978 } \\
\text { Treatment Group: }\end{array}$} \\
\hline & $\begin{array}{l}9 \text { Years } \\
\text { (1) }\end{array}$ & $\begin{array}{l}10 \text { Years } \\
\text { (2) }\end{array}$ & $\begin{array}{l}9 \text { Years } \\
\text { (3) }\end{array}$ & $\begin{array}{l}10 \text { Years } \\
\text { (4) }\end{array}$ \\
\hline Treatment & $\begin{array}{c}-0.25 * * * \\
(0.02)\end{array}$ & $\begin{array}{c}-0.27 * * * \\
(0.03)\end{array}$ & $\begin{array}{c}-0.34 * * * \\
(0.04)\end{array}$ & $\begin{array}{c}-0.36 * * * \\
(0.04)\end{array}$ \\
\hline After 1977 Law Change & $\begin{array}{l}0.22 * * * \\
(0.04)\end{array}$ & $\begin{array}{c}0.26 * * * \\
(0.04)\end{array}$ & $\begin{array}{c}0.20 * * * \\
(0.05)\end{array}$ & $\begin{array}{c}0.20 * * * \\
(0.04)\end{array}$ \\
\hline $\begin{array}{l}\text { Treatment* After } 1977 \\
\text { Law Change }\end{array}$ & $\begin{array}{l}-0.08^{* *} \\
(0.03)\end{array}$ & $\begin{array}{l}-0.09^{* *} \\
(0.04)\end{array}$ & $\begin{array}{l}-0.02 \\
(0.07)\end{array}$ & $\begin{array}{c}0.03 \\
(0.06)\end{array}$ \\
\hline 19 to 32 years old & $\begin{array}{l}2.18^{* * * *} \\
(0.14)\end{array}$ & $\begin{array}{c}2.09 * * * \\
(0.14)\end{array}$ & $\begin{array}{l}2.19 * * * \\
(0.29)\end{array}$ & $\begin{array}{l}2.12 * * * \\
(0.26)\end{array}$ \\
\hline 33 to 42 years old & $\begin{array}{l}1.20 * * * \\
(0.14)\end{array}$ & $\begin{array}{c}1.13^{* * *} \\
(0.14)\end{array}$ & $\begin{array}{l}1.24 * * * \\
(0.30)\end{array}$ & $\begin{array}{c}1.13 * * * \\
(0.26)\end{array}$ \\
\hline 43 to 52 years old & $\begin{array}{l}0.84 * * * \\
(0.15)\end{array}$ & $\begin{array}{c}0.79 * * * \\
(0.15)\end{array}$ & $\begin{array}{l}0.91 * * \\
(0.32)\end{array}$ & $\begin{array}{l}0.81 * * \\
(0.28)\end{array}$ \\
\hline 53 to 62 years old & $\begin{array}{c}0.49 * * \\
(0.16) \\
\end{array}$ & $\begin{array}{c}0.38 * * \\
(0.17) \\
\end{array}$ & $\begin{array}{c}0.49 \\
(0.35) \\
\end{array}$ & $\begin{array}{c}0.43 \\
(0.31) \\
\end{array}$ \\
\hline 1973 & $\begin{array}{c}-0.35 * * * \\
(0.03) \\
\end{array}$ & $\begin{array}{c}-0.35 * * * \\
(0.03) \\
\end{array}$ & & \\
\hline 1974 & $\begin{array}{c}-0.25 * * * \\
(0.03) \\
\end{array}$ & $\begin{array}{c}-0.25 * * * \\
(0.04) \\
\end{array}$ & & \\
\hline 1975 & $\begin{array}{c}-0.11 * * * \\
(0.03)\end{array}$ & $\begin{array}{c}-0.11 * * * \\
(0.04)\end{array}$ & & \\
\hline 1976 & $\begin{array}{r}-0.05 \\
(0.03) \\
\end{array}$ & $\begin{array}{c}-0.05 \\
(0.04) \\
\end{array}$ & & \\
\hline 1979 & $\begin{array}{c}0.20 * * * \\
(0.03)\end{array}$ & $\begin{array}{c}0.15 \\
(0.03) \\
\end{array}$ & & \\
\hline 1980 & $\begin{array}{c}0.20 * * * \\
(0.03)\end{array}$ & $\begin{array}{c}0.17 * * * \\
(0.03)\end{array}$ & & \\
\hline 1981 & $\begin{array}{c}0.29 * * * \\
(0.03)\end{array}$ & $\begin{array}{c}0.26 * * * \\
(0.04)\end{array}$ & & \\
\hline 1982 & $\begin{array}{l}0.08 * * \\
(0.03)\end{array}$ & $\begin{array}{c}0.04 \\
(0.04)\end{array}$ & & \\
\hline Constant & $\begin{array}{l}0.29 * \\
(0.16)\end{array}$ & $\begin{array}{l}0.37 * * \\
(0.15)\end{array}$ & $\begin{array}{c}0.31 \\
(0.29)\end{array}$ & $\begin{array}{c}0.39 \\
(0.26)\end{array}$ \\
\hline $\mathrm{R}^{2}$ & 0.97 & 0.98 & 0.84 & 0.82 \\
\hline
\end{tabular}

Source: Vital Statistics and 1980 Census.

Notes: Omitted age category in columns 1 and 2 is "over 62 years old". We omit dummy variables for the years 1977 and 1978. 
Table 3

Means and Standard Deviations of First Divorces beginning before 1977

\begin{tabular}{|c|c|c|c|c|}
\hline & $\begin{array}{c}9 \text { year } \\
\text { marriages }\end{array}$ & $\begin{array}{c}10 \text { year } \\
\text { marriages }\end{array}$ & $\begin{array}{c}8 \text { and } 9 \text { year } \\
\text { marriages }\end{array}$ & $\begin{array}{c}10 \text { and } 11 \\
\text { year } \\
\text { marriages }\end{array}$ \\
\hline Percent White (1 if white, 0 otherwise) & 0.822 & 0.804 & 0.810 & 0.797 \\
& $(0.382)$ & $(0.397)$ & $(0.392)$ & $(0.403)$ \\
\hline Age (in years) & 37.042 & 38.029 & 36.418 & 38.411 \\
& $(7.653)$ & $(7.678)$ & $(7.773)$ & $(7.512)$ \\
\hline Number of Children younger than 6 & 0.671 & 0.613 & 0.718 & 0.577 \\
& $(1.114)$ & $(1.114)$ & $(1.149)$ & $(1.079)$ \\
\hline Number of Children younger than 18 & 2.555 & 2.631 & 2.530 & 2.652 \\
& $(1.878)$ & $(2.035)$ & $(1.888)$ & $(2.023)$ \\
\hline Percent with less than high-school & 0.214 & 0.198 & 0.204 & 0.227 \\
& $(0.410)$ & $(0.398)$ & $(0.403)$ & $(0.419)$ \\
\hline Percent with more than high-school & 0.550 & 0.606 & 0.569 & 0.584 \\
& $(0.498)$ & $(0.489)$ & $(0.495)$ & $(0.493)$ \\
\hline Duration of divorce spell (in years) & 7.693 & 7.736 & 7.793 & 7.571 \\
& $(6.572)$ & $(6.636)$ & $(6.800)$ & $(6.526)$ \\
\hline Percent in 1985 CPS & 0.244 & 0.293 & 0.258 & 0.275 \\
& $(0.429)$ & $(0.455)$ & $(0.438)$ & $(0.447)$ \\
\hline Percent in 1990 CPS & 0.231 & 0.250 & 0.231 & 0.245 \\
& $(0.422)$ & $(0.433)$ & $(0.422)$ & $(0.430)$ \\
\hline Percent in 1995 CPS & 0.214 & 0.191 & 0.207 & 0.221 \\
& $(0.410)$ & $(0.393)$ & $(0.406)$ & $(0.415)$ \\
\hline N & 6836 & 6489 & 14107 & 11950 \\
\hline
\end{tabular}

Source: Authors' calculations from the 1980, 1985, 1990 and 1995 June CPSs. 
Table 4

Remarriage Probability for First Divorces beginning before 1977

\begin{tabular}{|c|c|c|c|c|}
\hline & $\begin{array}{c}\text { Pre-1977 } \\
\text { amendment } \\
(1)\end{array}$ & $\begin{array}{l}\text { Post-1977 } \\
\text { amendment } \\
\text { (2) }\end{array}$ & $\begin{array}{l}\text { Difference } \\
\text { (2)-(1) }\end{array}$ & $\begin{array}{l}\text { Difference-in- } \\
\text { differences } \\
\text { (Treatment- } \\
\text { Control) } \\
\end{array}$ \\
\hline \multicolumn{5}{|c|}{ Panel A } \\
\hline $\begin{array}{l}\text { A. Control group } \\
\text { 9- year marriages } \\
(\mathrm{n}=6836)\end{array}$ & $\begin{array}{c}0.128 \\
(0.005)\end{array}$ & $\begin{array}{c}0.054 \\
(0.005)\end{array}$ & $\begin{array}{c}-0.074^{\text {*** }} \\
(0.008)\end{array}$ & \\
\hline $\begin{array}{l}\text { B. Treatment group } \\
\text { 10-year marriages } \\
(\mathrm{n}=6489) \\
\end{array}$ & $\begin{array}{c}0.123 \\
(0.005)\end{array}$ & $\begin{array}{c}0.058 \\
(0.005)\end{array}$ & $\begin{array}{c}-0.065^{* * *} \\
(0.008)\end{array}$ & $\begin{array}{c}0.009 \\
(0.011)\end{array}$ \\
\hline \multicolumn{5}{|c|}{ Panel B } \\
\hline $\begin{array}{l}\text { C. Control group } \\
8 \text { and 9- year marriages } \\
(\mathrm{n}=14107)\end{array}$ & $\begin{array}{c}0.129 \\
(0.003)\end{array}$ & $\begin{array}{c}0.059 \\
(0.003)\end{array}$ & $\begin{array}{c}-0.070^{\text {**** }} \\
(0.006)\end{array}$ & \\
\hline $\begin{array}{l}\text { D. Treatment group } \\
10 \text { and } 11-\text { year old } \\
\text { marriages }(\mathrm{n}=11950) \\
\end{array}$ & $\begin{array}{c}0.122 \\
(0.004)\end{array}$ & $\begin{array}{c}0.065 \\
(0.004)\end{array}$ & $\begin{array}{c}-0.057^{* * *} \\
(0.006)\end{array}$ & $\begin{array}{c}0.013 \\
(0.008)\end{array}$ \\
\hline
\end{tabular}

Source: Authors' calculations from the 1980, 1985, 1990 and 1995 June CPSs.

Notes: Standard errors in parentheses. 
Table 5

Linear Probability

Dependent variable: Remarried $=1$

First Divorces beginning before 1977

\begin{tabular}{|c|c|c|}
\hline & $\begin{array}{c}\text { Treatment: } 10 \text { years of } \\
\text { marriage } \\
\text { Control: } 9 \text { years of marriage }\end{array}$ & $\begin{array}{c}\text { Treatment: } 10 \text { and } 11 \\
\text { years of marriage } \\
\text { Control: } 8 \text { and } 9 \text { years of } \\
\text { marriage }\end{array}$ \\
\hline 10-year marriages & $\begin{array}{c}0.004 \\
(0.007)\end{array}$ & $\begin{array}{c}0.007 \\
(0.005)\end{array}$ \\
\hline After law change & $\begin{array}{c}-0.018 * * \\
(0.008)\end{array}$ & $\begin{array}{l}-0.010^{*} \\
(0.006)\end{array}$ \\
\hline$(10-y e a r$ marriages $) *($ After law change $)$ & $\begin{array}{c}0.012 \\
(0.010)\end{array}$ & $\begin{array}{l}0.013 * \\
(0.007)\end{array}$ \\
\hline White (1 if white, 0 otherwise) & $\begin{array}{c}0.036 * * * \\
(0.006)\end{array}$ & $\begin{array}{c}0.038 * * * \\
(0.004)\end{array}$ \\
\hline Age (in years) & $\begin{array}{c}-0.008 * * * \\
(0.001)\end{array}$ & $\begin{array}{c}-0.007 * * * \\
(0.001)\end{array}$ \\
\hline Number of Children younger than 6 & $\begin{array}{c}0.005 \\
(0.003) \\
\end{array}$ & $\begin{array}{c}0.002 \\
(0.002) \\
\end{array}$ \\
\hline Number of Children younger than 18 & $\begin{array}{c}-0.006 * * * \\
(0.002)\end{array}$ & $\begin{array}{c}-0.005^{* * * *} \\
(0.001)\end{array}$ \\
\hline More than high-school (dummy) & $\begin{array}{c}0.001 \\
(0.009)\end{array}$ & $\begin{array}{c}0.001 \\
(0.006)\end{array}$ \\
\hline Less than high-school (dummy) & $\begin{array}{c}-0.018 * * \\
(0.008) \\
\end{array}$ & $\begin{array}{c}-0.013 * * \\
(0.005) \\
\end{array}$ \\
\hline Duration of divorce spell (in years) & $\begin{array}{c}-0.004 * * * \\
(0.001) \\
\end{array}$ & $\begin{array}{c}-0.005^{* * *} \\
(0.001) \\
\end{array}$ \\
\hline Duration of divorce spell squared & $\begin{array}{c}0.00019 * * * \\
(0.00004)\end{array}$ & $\begin{array}{c}0.00019 * * * \\
(0.00003)\end{array}$ \\
\hline 1985 June CPS Observation (dummy) & $\begin{array}{l}-0.003 \\
(0.007) \\
\end{array}$ & $\begin{array}{r}-0.010^{*} \\
(0.005) \\
\end{array}$ \\
\hline 1990 June CPS Observation (dummy) & $\begin{array}{l}-0.009 \\
(0.008) \\
\end{array}$ & $\begin{array}{c}-0.014 * * \\
(0.006) \\
\end{array}$ \\
\hline 1995 June CPS Observation (dummy) & $\begin{array}{c}-0.0001 \\
(0.008) \\
\end{array}$ & $\begin{array}{l}-0.005 \\
(0.006) \\
\end{array}$ \\
\hline Constant & $\begin{array}{c}0.400 * * * \\
(0.025)\end{array}$ & $\begin{array}{c}0.378 * * * \\
(0.018)\end{array}$ \\
\hline
\end{tabular}

Source: Authors' calculations from the 1980, 1985, 1990 and 1995 June CPSs.

Notes: Standard errors are reported in parentheses. Statistically significant at the 1 percent level $\left({ }^{* * *}\right)$, 5 percent level $\left({ }^{* *}\right)$, and 10 percent level $\left(^{*}\right)$. We report robust standard errors and cluster on individuals in the data more than once. 
Figure 1

Average Counts of divorces by marriage duration and calendar years

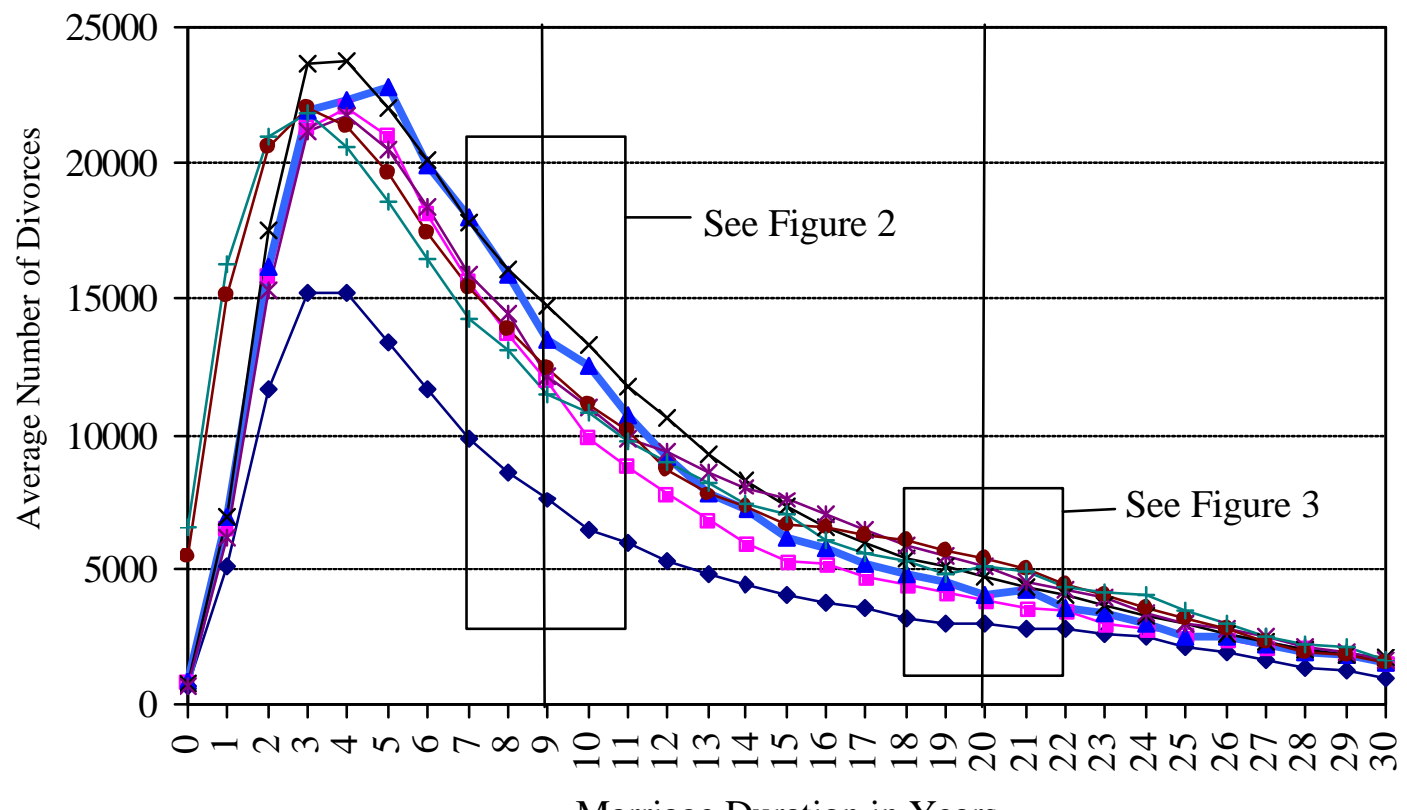

Marriage Duration in Years

$\bullet \bullet 69-73-74-77 \multimap 78 * 79-82 * 83-87 \rightarrow-88-92+93-95$

Sources: Vital Statistics divorce records, 25 states continuously reporting over the period 19681995 
Figure 2

Average Counts of divorces by marriage duration and calendar years

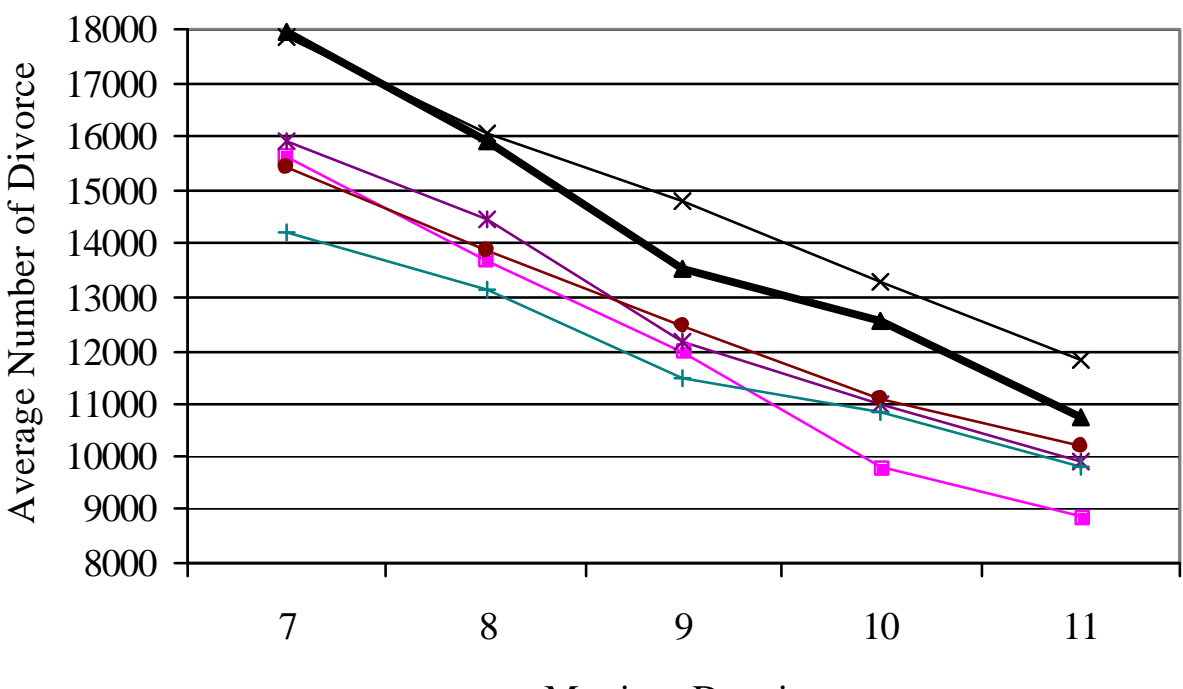

Marriage Duration

$-74-77 \multimap 78 \div 79-82 \div-83-87 \multimap 88-92 \multimap$ । $93-95$

Sources: Vital Statistics divorce records, 25 states continuously reporting over the period 19681995 
Figure 3

Average Counts of divorces by marriage duration and calendar years

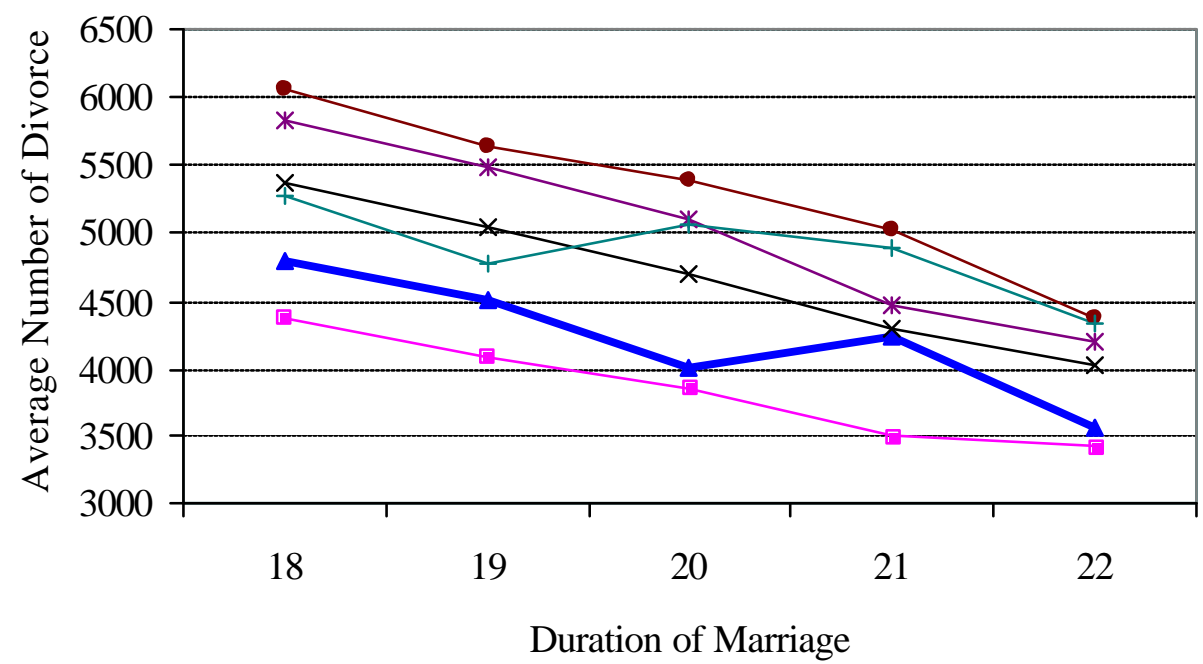

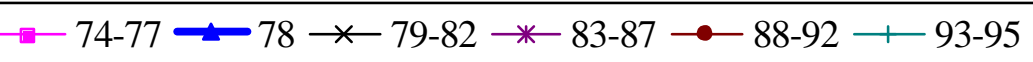

Sources: Vital Statistics divorce records, 25 states continuously reporting over the period 19681995 
Figure 4

Divorce rates by marriage duration

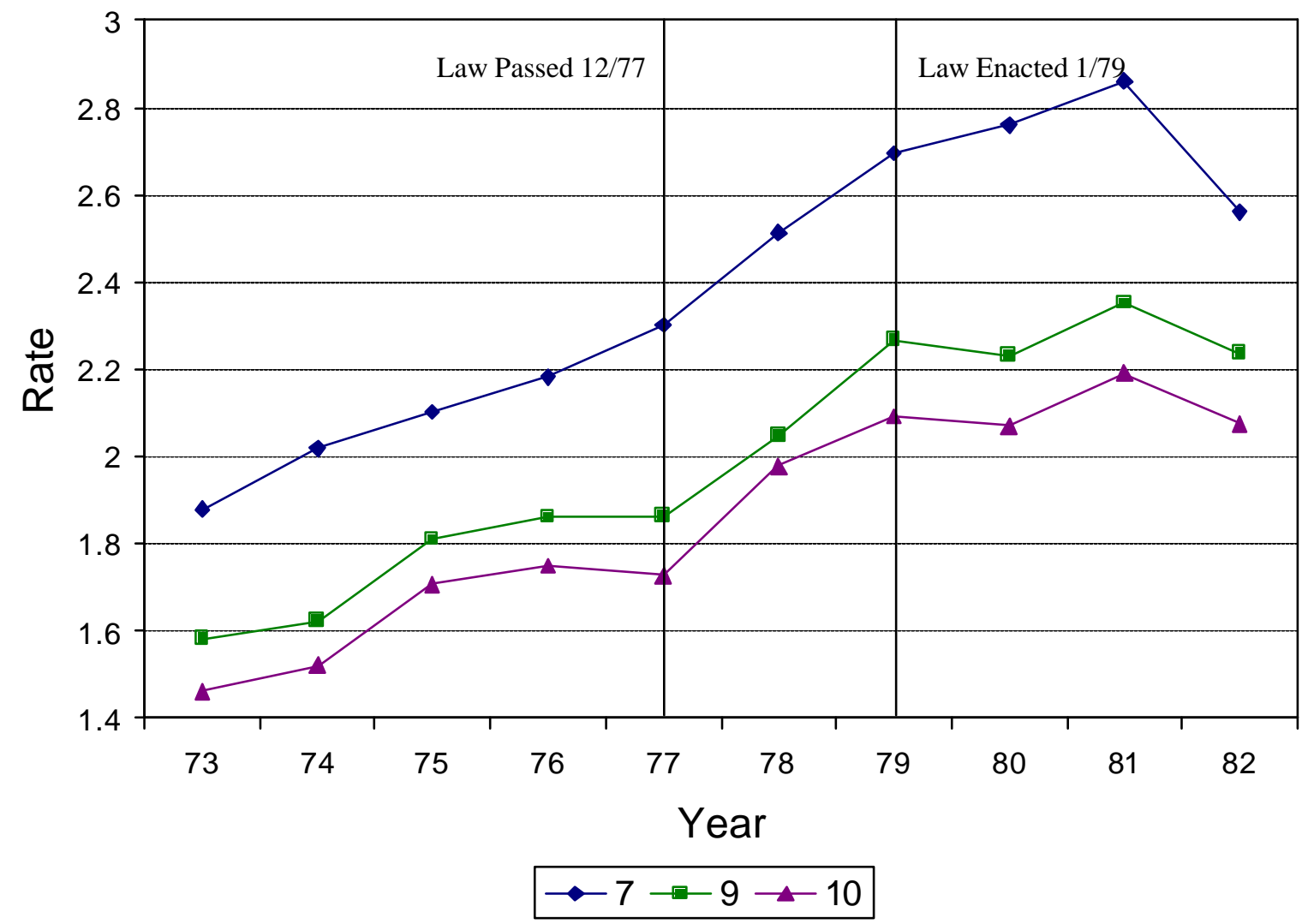

Source: Vital Statistics divorce records and 1980 Census for the 28 states continuously reporting divorce records over 1973-1982 
Figure 5

Remarriage rates by duration of previous marriage

First marriages that ended in divorce in 1976 or earlier

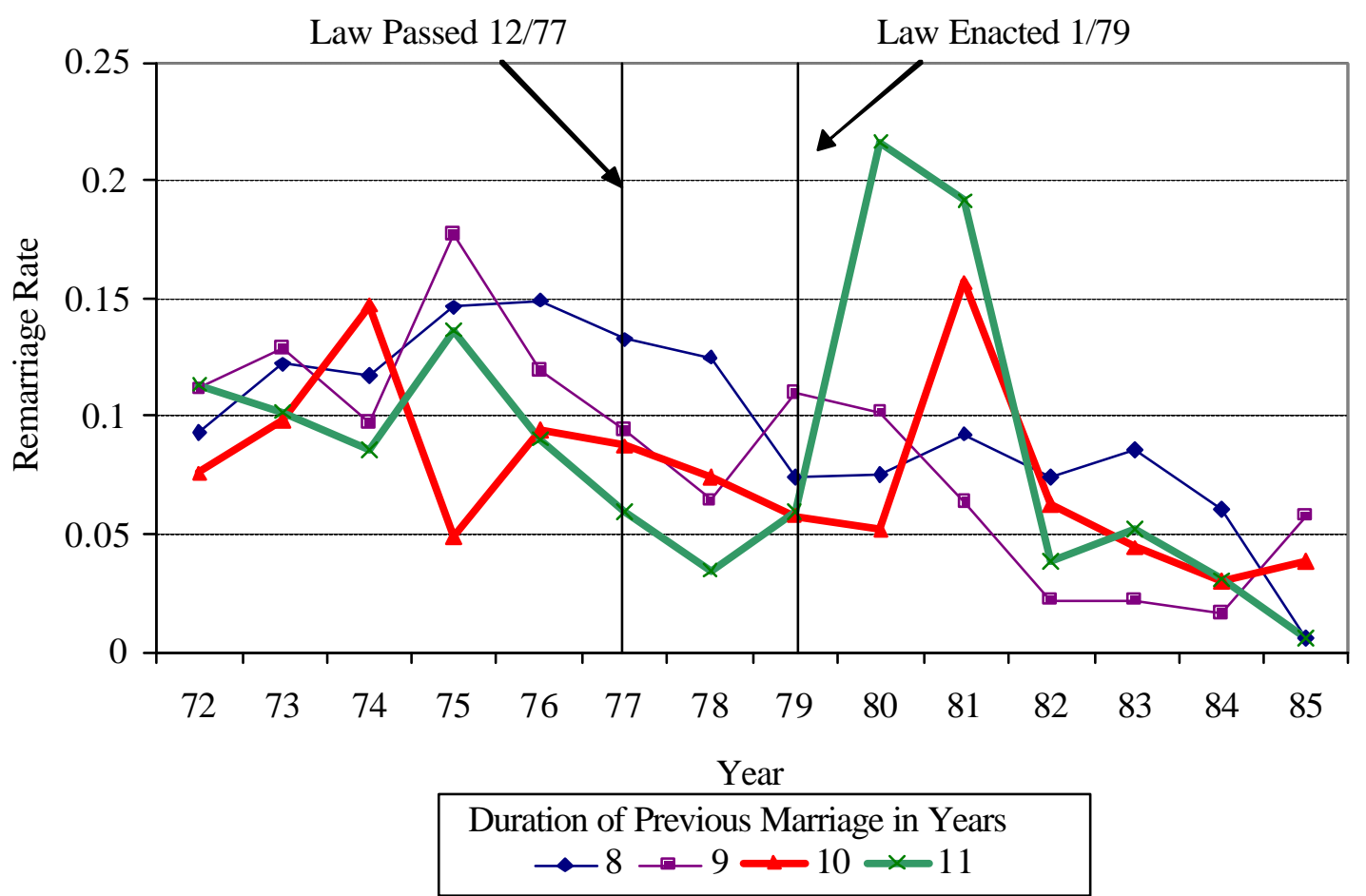

Source: 1980, 1985, 1990, and 1995 June supplements of the Current Population Survey. 


\section{RECENT WORKING PAPERS FROM THE \\ Center For Retirement Research at Boston College}

Living Arrangements and Supplemental Security Income Receipt Among the Aged Melissa M. Favreault and Douglas A. Wolf, February 2004

Interactions Between Social Security Reform and the Supplemental Security Income Program for the Aged

Paul S. Davies and Melissa M. Favreault, February 2004

Supply-Side Consequences of Social Security Reform: Impacts on Saving and Employment

Barry Bosworth and Gary Burtless, January 2004

It's All Relative: Understanding the Retirement Prospects of Baby-Boomers

Barbara A. Butrica, Howard M. Iams, and Karen E. Smith, November 2003

The Notional Defined Contribution Model: An Assessment of the Strengths and Limitations of a New Approach to the Provision of Old Age Security

John B. Williamson and Matthew Williams, October 2003

Simulating the Distributional Consequences of Personal Accounts: Sensitivity to Annuitization Options

Cori E. Uccello, Melissa M. Favreault, Karen E. Smith, and Lawrence H. Thompson, October 2003

Aggregate Implications of Defined Benefit and Defined Contribution Systems Francisco Gomes and Alexander Michaelides, September 2003

Can Unexpected Retirement Explain the Retirement-Consumption Puzzle? Evidence for Subjective Retirement Explanations Melvin Stephens Jr. and Steven J. Haider, August 2003

Employment, Social Security and Future Retirement Outcomes for Single Mothers Richard W. Johnson, Melissa M. Favreault, and Joshua H. Goldwyn, July 2003

The Outlook for Pension Contributions and Profits in the U.S. Alicia H. Munnell and Mauricio Soto, June 2003

Social Security Reform and the Exchange of Bequests for Elder Care Meta Brown, June 2003

All working papers are available on the Center for Retirement Research website (http://www.bc.edu/crr) and can be requested by e-mail (crr@bc.edu) or phone (617-552-1762). 